\begin{tabular}{|l|l|l||}
\hline \multicolumn{2}{|c|}{ PublisherInfo } \\
\hline \hline PublisherName & $:$ & BioMed Central \\
\hline \hline PublisherLocation & $:$ & London \\
\hline \hline PublisherImprintName & $:$ & BioMed Central \\
\hline \hline
\end{tabular}

\title{
SORAHSNs Continuing Medical Education programme
}

\begin{tabular}{||l|l|l||}
\hline \multicolumn{2}{|c||}{ ArticleInfo } \\
\hline \hline ArticleID & $:$ & 4236 \\
\hline \hline ArticleDOI & $:$ & $10.1186 /$ ccf-1999-webreport361 \\
\hline \hline ArticleCitationID & $:$ & webreport361 \\
\hline \hline ArticleSequenceNumber & $:$ & 24 \\
\hline \hline ArticleCategory & $:$ & Web report \\
\hline \hline ArticleFirstPage & $:$ & 1 \\
\hline \hline ArticleLastPage & $:$ & 2 \\
\hline \hline & & RegistrationDate : 1999-3-9 \\
ArticleHistory & $:$ & OnlineDate \\
\hline \hline ArticleCopyright & $:$ & Current Science Ltd1999-3-9 \\
\hline \hline ArticleGrants & $:$ & \\
\hline \hline ArticleContext & $:$ & 1305433 \\
\hline \hline
\end{tabular}




\section{Overview}

This Continuing Medical Education page of the SORAHSNs website is dedicated to interactive patient simulations. There are three complete cases; shortness of breath, emergency and trauma. The user is able to determine the fate of a patient brought into the virtual emergency room. Decisions on the best course of treatment for the patient is left up to the user. Each decision in the treatment is assessed and advice given. There are decisions to be made on all aspects of care, from medication to the best resusitation equipment to be used. Vital statistics as well as past history and medication details are shown. X-ray pictures are visible, and results of blood analyses given.

\section{Content}

This is a well designed and fun site, but with a serious education element. It provides an excellent way of learning, with plenty of advice on the best decisions for the patient.

\section{September 1999}

New cases on the site are constantly being added. Two new cases are under construction, Heartburn: Life in the ER and The Trauma Zone.

\section{Evaluation}

Access to the site is free.

\section{References}

1. Southwestern Ontario Academic Health Science Network. [http://ahsn2.largnet.on.ca/ce/] 